\title{
A Case-Control Study of Levothyroxine and the Risk of Colorectal Cancer
}

\author{
Gad Rennert, Hedy S. Rennert, Mila Pinchev, Stephen B. Gruber \\ Manuscript received February 8, 2009; revised June 23, 2009; accepted January \\ 22,2010
}

Correspondence to: Gad Rennert, MD, PhD, Department of Community Medicine and Epidemiology, Carmel Medical Center, 7 Michal St, Haifa 34362, Israel (e-mail: rennert@tx.technion.ac.il).

Levothyroxine is a synthetic $\mathrm{T}_{4}$ hormone commonly used to treat thyroid disease. Increased incidence of mostly autoimmune thyroid disease has been associated with breast and other malignancies, and thyroid hormone levels might also be associated with risk of colorectal cancer (CRC). In this population-based matched case-control study (2566 pairs) of CRC in northern Israel, use of levothyroxine for at least $\mathbf{5}$ years was assessed using structured interviews and validated by prescription records. The analysis included use of statins, aspirin, and hormone replacement therapy; CRC family history; physical activity; vegetable consumption; ethnicity; age; and sex. All statistical tests were two-sided. The use of levothyroxine was associated with a statistically significantly reduced relative risk of CRC (odds ratio $=0.59,95 \%$ confidence interval $=0.43$ to $0.82, P=.001$ ). This association remained statistically significant after adjustment for age, sex, use of aspirin and statins, sports activity, family history of CRC, ethnic group, and level of vegetable consumption (odds ratio $=0.60,95 \%$ confidence interval $=0.44$ to $0.81, P=.001$ ). No statistically significant interactions were seen between use of levothyroxine and aspirin, statins, or hormone replacement therapy.

\section{J Natl Cancer Inst 2010;102:568-572}

Colorectal cancer (CRC) is the second most commonly diagnosed cancer in Israel, with approximately 3200 new cases and 1500 deaths in 2006 (1). Thyroid disease may be associated with elevated risk of breast (2-9), stomach (10), and pancreatic cancers (11), but its relationship with CRC is unknown. Increased risk of cancer has been associated with elevated antithyroid antibodies $(2,3,5,11,12)$, possibly reflecting impaired immunoregulation caused by malignant cells. Hypothyroidism, use of thyroid medications, and low to normal levels of the thyroid hormone $\mathrm{T}_{4}$ have been associated with increased risk of postmenopausal breast cancer (4). In addition, major pathways in the development of CRC have been shown to be negatively regulated by thyroid hormone (13). Levothyroxine is a synthetic $T_{4}$ hormone that is used to treat patients with hypothyroidism. We studied the possible association between use of levothyroxine and occurrence of CRC in a population in northern Israel.
The Molecular Epidemiology of Colorectal Cancer (MECC) study is a population-based case-control study of incident CRC patients in northern Israel and control subjects in the general population matched by year of birth, sex, residence (defined by primary clinic location), and ethnic group (Jewish vs non-Jewish). All subjects were interviewed in person to obtain information about their personal and family history of cancer, reproductive history, medical history, medication use, and health habits, including a previously described dietary questionnaire (14). The variables included in this analysis were use of levothyroxine for at least 5 years; use of statins for at least 5 years; daily aspirin use for at least 3 years; ever use of hormone replacement therapy (HRT); first-degree family history of CRC; physical activity, yes or no (15); vegetable consumption of at least five servings per day (16); ethnicity; age; and sex. All variables are known risk factors for CRC (see Supplementary
Methods, available online). We matched self-reports of levothyroxine use against prescription records when available. Unconditional and conditional stepwise backward elimination logistic regression models were used. Statistical analyses were performed using SPSS v 15.0 (SPSS, Inc, Chicago, IL). All statistical tests were two-sided. Institutional review boards at Carmel Medical Center and the University of Michigan approved all procedures.

Data from 2648 patients and 2566 control subjects (2566 matched pairs) were available for analysis. The response rate was $70 \%$ of all eligible case patients and $59 \%$ of eligible control subjects. Prescription records were validated for 177 (93.7\%) of the 189 self-reported levothyroxine users for whom computerized data were available, with similar agreement for case patients and control subjects.

As expected, Ashkenazi Jews were overrepresented among case patients compared with non-Ashkenazi Jews (17) and Arabs, in keeping with known CRC rates in Israel (18). Family history (first-degree relatives), sports participation, vegetable consumption, and use of aspirin, statins, and HRT differed statistically significantly between case patients and control subjects (Table 1).

Levothyroxine use was reported more by control subjects than by case patients (5.1\% vs $3.0 \%$, respectively, $P<.001$ ) and was associated with a statistically significant reduction in risk of CRC (odds ratio $[\mathrm{OR}]=$ $0.59,95 \%$ confidence interval $[\mathrm{CI}]=0.43$ to $0.82, P=.001)$. Levothyroxine use differed statistically significantly between male and female control subjects $(2.0 \%$ vs $8.2 \%$, respectively, $P<.001)$, reflecting known differences in hypothyroidism by sex (19). The negative association between levothyroxine use and CRC in men was not statistically significant $(\mathrm{OR}=0.75,95 \% \mathrm{CI}=$ 0.42 to $1.36, P=.35)$, whereas the negative association in women was strong $(\mathrm{OR}=$ $0.54,95 \% \mathrm{CI}=0.38$ to $0.75, P<.0001)$. Estrogen and/or progestin replacement treatments in peri/postmenopausal women have been shown to be associated with reduced risk of CRC (20-24). HRT use in our study was associated with a statistically significantly reduced risk of CRC (OR = $0.64,95 \% \mathrm{CI}=0.50$ to $0.83, P=.001)$. In a 
univariate analysis, levothyroxine use was associated with a statistically significantly reduced risk of CRC in postmenopausal women $(\mathrm{OR}=0.53,95 \% \mathrm{CI}=0.37$ to 0.74 , $P<.001)$ overall; this effect remained statistically significant among non-HRT users $(\mathrm{OR}=0.49,95 \% \mathrm{CI}=0.33$ to $0.73, P<$ $.001)$ but not among HRT users (OR = $0.90,95 \% \mathrm{CI}=0.35$ to $\left.2.36, P_{\text {interaction }}=.19\right)$. A statistically significant interaction was previously found between use of HRT and aspirin with respect to the risk of CRC (24) and was included in the final model in this study.

After adjustment for potential confounders, the association between levothyroxine use and reduced risk of CRC remained statistically significant $(\mathrm{OR}=$

Table 1. Comparison of major study variables between case patients and control subjects in the Molecular Epidemiology of Colorectal Cancer study in Israel*

\begin{tabular}{|c|c|c|c|c|c|c|}
\hline \multirow[b]{3}{*}{ Variable } & \multicolumn{3}{|c|}{ Unpaired } & \multicolumn{3}{|c|}{ Paired } \\
\hline & $\begin{array}{c}\text { Case } \\
\text { patients } \\
(n=2648)\end{array}$ & $\begin{array}{c}\text { Control } \\
\text { subjects } \\
(n=2566)\end{array}$ & & $\begin{array}{c}\text { Case } \\
\text { patients } \\
(n=2566)\end{array}$ & $\begin{array}{c}\text { Control } \\
\text { subjects } \\
(\mathrm{n}=2566)\end{array}$ & \\
\hline & No. (\%) & No. (\%) & $P+$ & No. (\%) & No. (\%) & $P+$ \\
\hline Sex & & & .99 & & & 1.00 \\
\hline Men & $1342(50.7)$ & $1301(50.7)$ & & $1301(50.7)$ & $1301(50.7)$ & \\
\hline Women & $1306(49.3)$ & $1265(49.3)$ & & 1265 (49.3) & $1265(49.3)$ & \\
\hline Age, mean, y & 69.9 & 70.6 & .06 & 69.8 & 70.6 & .03 \\
\hline Ethnicity & & & .39 & & & .30 \\
\hline Non-Jews & $348(13.1)$ & $317(12.4)$ & & $342(13.3)$ & $317(12.4)$ & \\
\hline Jews & $2300(86.9)$ & $2249(87.6)$ & & $2224(86.7)$ & $2249(87.6)$ & \\
\hline Jewish ethnicity & & & $<.001$ & & & $<.001$ \\
\hline $\begin{array}{l}\text { Ashkenazi } \\
\text { (\% of Jews) }\end{array}$ & $1793(78.0)$ & $1607(71.5)$ & & $1734(78.0)$ & 1607 (71.5) & \\
\hline $\begin{array}{l}\text { Sephardi } \\
\text { (\% of Jews) }\end{array}$ & 458 (19.9) & $602(26.8)$ & & $444(20.0)$ & $602(26.8)$ & \\
\hline Mixed (\% of Jews) & $49(2.1)$ & 40 (1.8) & & $46(2.1)$ & 40 (1.8) & \\
\hline $\begin{array}{l}\text { Levothyroxine use } \\
\text { for } \geq 5 \text { y }\end{array}$ & $77(3.0)$ & $129(5.1)$ & $<.001$ & $74(3.0)$ & $129(5.1)$ & $<.001$ \\
\hline $\begin{array}{l}\text { Family history of } \\
\text { CRC among first- } \\
\text { degree relatives }\end{array}$ & $304(12.0)$ & $204(8.1)$ & $<.001$ & $295(12.0)$ & $204(8.1)$ & $<.001$ \\
\hline Sports activity & 769 (29.9) & $1063(41.5)$ & $<.001$ & $750(30.1)$ & $1063(41.5)$ & $<.001$ \\
\hline $\begin{array}{l}\text { Vegetable intake } \\
\text { of } \geq 5 \text { servings } \\
\text { per day }\end{array}$ & $1402(56.5)$ & $1552(60.9)$ & .002 & $1359(56.5)$ & $1552(60.9)$ & .002 \\
\hline $\begin{array}{l}\text { Aspirin use daily } \\
\text { for } \geq 3 \text { y }\end{array}$ & $371(14.5)$ & $584(22.9)$ & $<.001$ & $364(14.6)$ & $584(22.9)$ & $<.001$ \\
\hline Statin use for $\geq 5$ y & $173(6.8)$ & $293(12.5)$ & $<.001$ & $168(6.8)$ & $293(12.5)$ & $<.001$ \\
\hline $\begin{array}{c}\text { Ever HRT use } \\
\text { (\% of all } \\
\text { women) }\end{array}$ & 70 (6.6) & $126(10.8)$ & .001 & 69 (6.8) & $126(10.8)$ & .001 \\
\hline
\end{tabular}

* Case patients were incident CRC patients and control subjects were members of the general population matched by year of birth, sex, residence (defined by primary clinic location), and ethnic group (Jewish vs non-Jewish). The 3- and 5-year cut points for use of aspirin, levothyroxine, and statin were selected to capture long-term use. Percentage discrepancies are because of missing values in some of the variables. $\mathrm{CRC}=$ colorectal cancer; $\mathrm{HRT}=$ hormone replacement therapy.

$+P$ values for comparison between case patients and control subjects calculated using the two-sided $\chi^{2}$ test and the $t$ test for age.
$0.60,95 \% \mathrm{CI}=0.44$ to $0.81, P=.001)$ (Table 2). The crude and adjusted odds ratios for levothyroxine use were similar in the conditional and unconditional analyses. In the fully adjusted model for postmenopausal women, levothyroxine use was aswith a statistically significant $\mathrm{CI}=0.41$ to $0.87, P=.008)$ (Table 2 ).

Our data indicate a strong inverse association between risk of CRC and long-term use of levothyroxine. Although there are few reports relating thyroid hormones and CRC, thyroid dysregulation is reproducibly associated with risk of breast cancer (2-5), and its relationship to pancreatic (11) and gastric $(10,25)$ cancers has been discussed.

\section{How} women by the use of hormone replacement therapy.

\section{Limitations}

The use of retrospective data may introduce recall bias. The slightly unbalanced participation rates of case patients and control subjects could also result in selection bias. The study was underpowered to test the association in premenopausal women.

From the Editors

Preclinical data (13) suggest that transactivation by the Bcat/tcf1 transcription factor of the Cyclin D promoter is negatively regulated by thyroid hormone. It also showed that the T3-bound receptor inhibits the transcription of cyclin D1 through the Tcf/Lef-1 site, which is positively regulated by the Wnt-signaling pathway. Because the Wnt pathway is a central pathway in causation of sporadic CRC, as determined in humans (26), hormones that inhibit this pathway could potentially be considered as cancer prevention agents. Thyroid hormones have also been shown to inhibit estrogen-induced degradation of the estrogen receptor- $\alpha$ protein in breast 


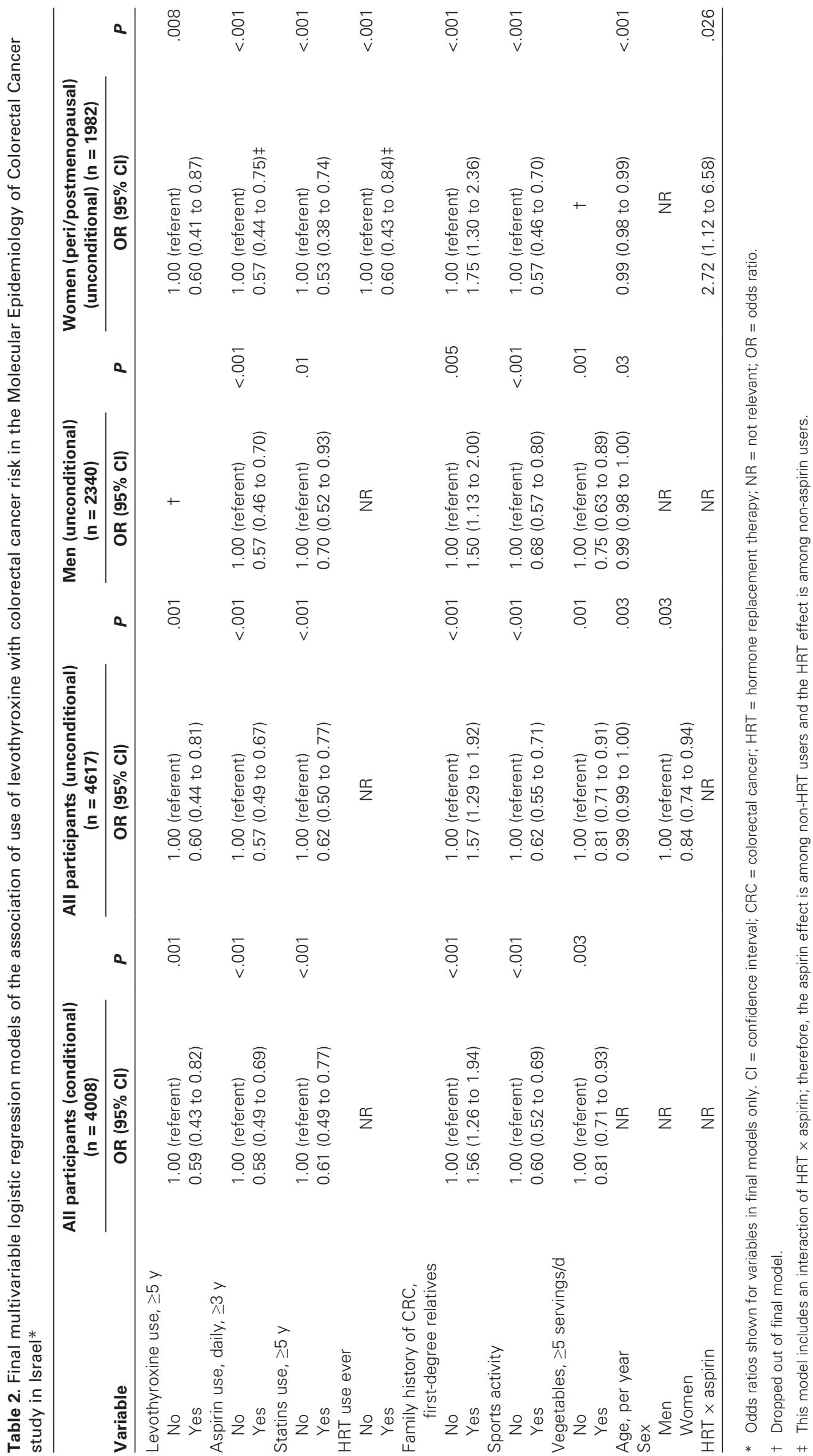


cancer (27), induce formation of aberrant thyroid hormone receptors in hepatocytes (28,29), suppress pituitary tumortransforming 1 (PTT1) activity (30), regulate cell cycle progression and proliferation in estrogen responsive breast ductal cell lines, and raise 553 levels (31). HRT $(21,32,33)$ and thyroid hormones are associated with reduction in risk of CRC in our study, but both are suspected to be associated with an elevated risk of breast cancer (5-9,34), thus suggesting a common mechanism. In vitro studies $(35,36)$ suggested cross talk between the estrogen receptor and thyroid hormone receptors; thyroid hormone $\mathrm{T}_{3}$ increased estrogen receptor- $\alpha$ levels, resulting in increased progesterone receptor levels, prolactin production, and tumor growth (35). It has also been shown that chronic estradiol treatment reduces total $\mathrm{T}_{4}$ levels in ovariectomized rats (36). Use of HRT and levothyroxine by women with hypothyroidism was shown to change the levels of thyroid-stimulating hormone and free $T_{4}$ (37) and to require additional levothyroxine intervention (38). This change in thyroidstimulating hormone and free $\mathrm{T}_{4}$ levels is probably not mediated through changes in sex hormone-binding globulin protein levels (39) and is noted with oral but not with transdermal HRT (40). Slattery et al. (41) demonstrated that the presence of the $\mathrm{R}$ allele of the estrogen receptor- $\beta$ gene was associated with reduced risk of CRC among HRT users but increased risk among nonusers. The same association may account for our reported differences in risk of CRC magnitude associated with levothyroxine use in HRT users and nonusers.

One of the limitations of our study is possible recall bias because exposure data were collected retrospectively. However, because a levothyroxine-CRC risk association was not known, participants were unlikely to differentially report on this. Furthermore, we were able to validate selfreported levothyroxine use through a prescription database, although we did not have data regarding dose or duration of use. Other limitations were that the slightly imbalanced participation rates of case patients and control subjects could result in selection bias and that the study was underpowered to study associations in premenopausal women.

In conclusion, we found that long-term use of levothyroxine is associated with a reduction in risk of CRC after adjustment for other known risk factors. Together with aspirin and statins, these agents provide powerful tools for combating CRC. However, the disappearance of the risk reduction effect of aspirin and levothyroxine in HRT users calls for further study and caution in considering HRT for CRC prevention.

\section{References}

1. Israel National Cancer Registry. Ministry of Health. http://www.health.gov.il/pages/default .asp? maincat $=22 \&$ catId $=56 \&$ PageId $=688$. Accessed July 2009.

2. Jiskra J, Barkmanova J, Limanova Z, et al. Thyroid autoimmunity occurs more frequently in women with breast cancer compared to women with colorectal cancer and controls but it has no impact on relapse-free and overall survival. Oncol Rep. 2007;18(6): 1603-1611.

3. Giustarini E, Pinchera A, Fierabracci P, et al. Thyroid autoimmunity in patients with malignant and benign breast diseases before surgery. Eur 7 Endocrinol. 2006;154(5):645-649.

4. Kuijpens JL, Nyklíctek I, Louwman MW, Weetman TA, Pop VJ, Coebergh JW. Hypothyroidism might be related to breast cancer in post-menopausal women. Thyroid. 2005;15(11):1253-1259.

5. Giani C, Fierabracci P, Bonacci R, et al. Relationship between breast cancer and thyroid disease: relevance of autoimmune thyroid disorders in breast malignancy. 7 Clin Endocrinol Metab. 1996;81(3):990-994.

6. Kapdi CC, Wolfe JN. Breast cancer. Relationship to thyroid supplements for hypothyroidism. FAMA. 1976;236(10):1124-1127.

7. Morabia A, Szklo M, Stewart W, Schuman L, Thomas DB, Zacur HA. Thyroid hormones and duration of ovulatory activity in the etiology of breast cancer. Cancer Epidemiol Biomarkers Prev. 1992;1(5):389-393.

8. Gago-Dominguez M, Castelao JE. Role of lipid peroxidation and oxidative stress in the association between thyroid diseases and breast cancer. Crit Rev Oncol Hematol. 2008;68(2):107-114.

9. Smyth PP. The thyroid and breast cancer: a significant association? Ann Med. 1997;29(3):189-191.

10. Syrigos KN, Konstantoulakis MM, Constantoulakis M, Marafelia P, Koutras D, Golematis BC. Thyroid autoantibodies and thyroid function in patients with gastric cancer. Acta Oncol. 1994;33(8):905-907.

11. Fyssas I, Syrigos KN, Konstantoulakis MM, et al. Thyroid autoantibodies and thyroid function in patients with pancreatic adenocarcinoma. Acta Oncol. 1997;36(1):65-68.

12. Jiskra J, Límanová Z, Barkmanová J, Smutek D, Friedmannová $Z$. Autoimmune thyroid diseases in women with breast cancer and colorectal cancer. Physiol Res. 2004;53(6):693-702.

13. Natsume H, Sasaki S, Kitagawa $M$, et al. Beta-catenin/Tcf-1-mediated transactivation of cyclin D1 promoter is negatively regulated by thyroid hormone. Biochem Biophys Res Commun. 2003;309(2):408-413.

14. Poynter JN, Gruber SB, Higgins PDR, et al. Statins and the risk of colorectal cancer. N Engl 7 Med. 2005;352(21):2184-2192.

15. Baecke JA, Burema J, Frijters JE. A short questionnaire for the measurement of habitual physical activity in epidemiological studies. Am 7 Clin Nutr. 1982;36(5):936-942.

16. Yizhaki D, Rennert HS, Rosen G, Rennert G. Validity and reproducibility of a semiquantitative food frequency questionnaire adapted to an Israeli population. Open Nutr 7 . 2008;2:9-14.

17. Barchana M, Liphshitz I, Rozen P. Trends in colorectal cancer incidence and mortality in the Israeli Jewish ethnic populations. Fam Cancer. 2004;3(3-4):207-214.

18. Barchana M. Colorectal cancer. In: Freedman LS, Edwards BK, Ries LAG, Young JL, eds. Cancer Incidence in Four Member Countries of the MECC Compared With US SEER. National Cancer Institute MECC Monograph. Publ No. 06-5873. 2006:41-50.

19. Rennert G, Peterburg Y. Prevalence of selected chronic diseases in Israel. Isr Med Assoc 7. 2001;3(6):404-408.

20. Kampman E, Potter JD, Slattery ML, Caan BJ, Edwards S. Hormone replacement therapy, reproductive history, and colon cancer: a multicenter, case-control study in the United States. Cancer Causes Control. 1997; 8(2):146-158.

21. Nelson HD, Humphrey LL, Nygren P, Teutsch SM, Allan JD. Postmenopausal hormone replacement therapy: scientific review. 7AMA. 2002;288(7):872-881.

22. Newcomb PA, Zheng Y, Chia VM, et al. Estrogen plus progestin use, microsatellite instability, and the risk of colorectal cancer in women. Cancer Res. 2007;67(15):7534-7539.

23. Chlebowski RT, Wactawski-Wende J, Ritenbaugh C, et al. Women's Health Initiative Investigators. Estrogen plus progestin and colorectal cancer in postmenopausal women. $N$ Engl 7 Med. 2004;350(10): 991-1004.

24. Rennert G, Rennert HS, Pinchev M, Lavi O, Gruber SB. HRT use and risk of colorectal cancer. 7 Clin Oncol. 2009;27(27):4542-4547.

25. Iishi H, Tatsuta $M$, Baba $M$, Yamamoto R, Taniguchi H. Enhancement by thyroxine of gastric carcinogenesis induced by $\mathrm{N}$-methyl$\mathrm{N}^{\prime}$-nitro-N-nitrosoguanidine in Wistar rats. Br 7 Cancer. 1993;68(3):515-518.

26. Vogelstein B, Fearon ER, Hamilton SR, et al. Genetic alterations during colorectal-tumor development. $N$ Engl 7 Med. 1988;319(9): 525-532.

27. Alarid ET, Preisler-Mashek MT, Solodin NM. Thyroid hormone is an inhibitor of estrogen-induced degradation of estrogen receptor-alpha protein: estrogen-dependent proteolysis is not essential for receptor transactivation function in the pituitary. Endocrinology. 2003;144(8):3469-3476.

28. Chan IH, Privalsky ML. Thyroid hormone receptors mutated in liver cancer function as 
distorted antimorphs. Oncogene. 2006;25(25): 3576-3588.

29. Cheng SY. Thyroid hormone receptor mutations in cancer. Mol Cell Endocrinol. 2003; 213(1):23-30.

30. Chen RN, Huang YH, Yeh CT, Liao CH, Lin KH. Thyroid hormone receptors suppress pituitary tumor transforming gene 1 activity in hepatoma. Cancer Res. 2008;68(6): 1697-1706.

31. Dinda S, Sanchez A, Moudgil V. Estrogenlike effects of thyroid hormone on the regulation of tumor suppressor proteins, p53 and retinoblastoma, in breast cancer cells. Oncogene. 2002;21(5):761-768.

32. Beral V, Banks E, Reeves G. Evidence from randomised trials on the long-term effects of hormone replacement therapy. Lancet. 2002; 360(9337):942-944.

33. Ravdin PM, Cronin KA, Howlader N, et al. The decrease in breast-cancer incidence in 2003 in the United States. $N$ Engl 7 Med. 2007;356(16):1670-1674.

34. Fernandez E, Gallus S, Bosetti C, Franceschi S, Negri E, La Vecchia C. Hormone replacement therapy and cancer risk: a systematic analysis from a network of case-control studies. Int 7 Cancer. 2003;105(3):408-412.
35. Fujimoto N, Jinno N, Kitamura S. Activation of estrogen response element dependent transcription by thyroid hormone with increase in estrogen receptor levels in a rat pituitary cell line, GH3. 7 Endocrinol. 2004;181(1):77-83.

36. Böttner M, Wuttke W. Chronic treatment with low doses of estradiol affects pituitary and thyroid function in young and middle-aged ovariectomized rats. Biogerontology. 2005;6(4):261-269.

37. Grüning T, Zöphel K, Wunderlich G, Franke WG. Influence of female sex hormones on thyroid parameters determined in a thyroid screening. Clin Lab. 2007;53(9-12):547-553.

38. Schindler AE. Thyroid function and postmenopause. Gynecol Endocrinol. 2003;17(1):79-85

39. Lecomte P, Lecureuil N, Osorio-Salazar C, Lecureuil M, Valat C. Effects of suppressive doses of levothyroxine treatment on sexhormone-binding globulin and bone metabolism. Thyroid. 1995;5(1):19-23.

40. Shifren JL, Desindes S, McIlwain M, Doros G, Mazer NA. A randomized, open-label, crossover study comparing the effects of oral versus transdermal estrogen therapy on serum androgens, thyroid hormones, and adrenal hormones in naturally menopausal women. Menopause. 2007;14(6):985-994.
41. Slattery ML, Sweeney C, Murtaugh M, et al. Associations between ERalpha, ERbeta, and $\mathrm{AR}$ genotypes and colon and rectal cancer. Cancer Epidemiol Biomarkers Prev. 2005;14(12): 2936-2942.

\section{Funding}

National Cancer Institute (1R01CA81488 to S.B.G. and G.R.).

\section{Notes}

The funders did not have any involvement in the design of the study; the collection, analysis, and interpretation of the data; the writing of the manuscript; or the decision to submit the manuscript for publication.

Affiliations of authors: Department of Community Medicine and Epidemiology, Carmel Medical Center and Bruce Rappaport Faculty of Medicine, Technion-Israel Institute of Technology and Clalit Health Services National Cancer Control Center, Haifa, Israel (GR, HSR, MP); Department of Epidemiology, Department of Internal Medicine, and Department of Human Genetics, University of Michigan, Ann Arbor, MI (SBG). 